Article

\title{
Investors' Aspirations toward Social Impact: A Portfolio-Based Analysis
}

\author{
Leonardo Boni $^{1, * \mathbb{D}}$, Laura Toschi ${ }^{2} \mathbb{D}$ and Riccardo Fini ${ }^{2}$ \\ 1 Department of Management, Economics and Industrial Engineering, Politecnico di Milano, \\ Via Lambruschini, 4/B, 20156 Milano, Italy \\ 2 Department of Management, University of Bologna, Via Capo di Lucca, 34, 40126 Bologna, Italy; \\ laura.toschi@unibo.it (L.T.); riccardo.fini@unibo.it (R.F.) \\ * Correspondence: leonardo.boni@polimi.it
}

check for

updates

Citation: Boni, L.; Toschi, L.; Fini, R. Investors' Aspirations toward Social Impact: A Portfolio-Based Analysis. Sustainability 2021, 13, 5293. https:// doi.org/10.3390/su13095293

Academic Editor: António Abreu

Received: 22 March 2021

Accepted: 5 May 2021

Published: 10 May 2021

Publisher's Note: MDPI stays neutral with regard to jurisdictional claims in published maps and institutional affiliations.

Copyright: (c) 2021 by the authors. Licensee MDPI, Basel, Switzerland. This article is an open access article distributed under the terms and conditions of the Creative Commons Attribution (CC BY) license (https:// creativecommons.org/licenses/by/ $4.0 /)$.

\begin{abstract}
In the last ten years, we have witnessed a proliferation of investors claiming blended value strategies, i.e., pursuing both economic and social returns in their investments. Aside from this rush for self-selecting in a blended value finance context, we still do not know to what extent the investors' claims actually reflect investment decisions. Evidence suggests that, in some cases, such investors tend to maximize the social performance over the financial performance; in some others, the effect is reverted, but literature currently lacks studies aligning the analysis of the investment decisions with the investment portfolios. Yet, it is still unclear whether blended value investment decisions are enacted as a result of investors' deliberate strategies and what influences this relationship. In this paper we tackle this issue, analyzing the extent to which investors' finance firms pursuing goals aligned with their strategic aspirations. Specifically, adopting a Fractional Logistic Regression model, we test the effect of investors' aspirations toward social impact on the extent to which their investees (i.e., the portfolio of firms in which they invest) pursue social returns. Results suggest the existence of a positive and significant investor-portfolio alignment effect (i.e., the higher the investors' aspirations toward social impact, the higher the number of investees with higher social aspirations). Yet, this effect is influenced by contingencies at both investor and portfolio levels. Investors with strong aspirations toward social impact that: (i) invest in countries with high levels of social inequality, and (ii) are located in countries that support social progress and maximize, in their portfolios, the presence of businesses pursuing social impact. We discuss implications for future researchers, policymakers and practitioners.
\end{abstract}

Keywords: impact investing; blended value; alignment; aspirations

\section{Introduction}

The concept of social impact-the positive effects on society generated by the outputs of a given business strategy [1] - has been vigorously debated, stimulating the financial sphere to increasingly include it in their objectives [2,3]. As common wisdom suggests, mainstream financial actors (i.e., traditional economically oriented intermediaries) reject the idea of paying a premium for the generation of social impact, due to temporal misalignment of goals $[4,5]$. Traditional investors generally search for short-term economic returns, while social-impact-based investments need a longer-term perspective. Yet, the link between social impact and finance is not a modern deviation. For instance, 17th century Quakers in England were among the first to align their investment with values in which they believed. In the 19th century, Shaker congregations in the United States of America financed businesses aligned with their religious values [6]. More recently, 1970s environmental concerns headed by Rachel Carson's Silent Spring book aimed at moving investments for the conservation of the planet harmed by pollution. In different forms, economic and social impact combined on the global market stage for centuries. Nowadays, finance and social impact are linked more than ever, but this trend may hide potential threats. 
After the financial crisis started in 2008-2009, and to contrast the shameless greed of disastrous traditional practices, the financial industry directed its attention toward blended value [6-8], looking for solutions combining social and economic values, such as impact investing strategies $[9,10]$.

What we see now is a huge proliferation of actors willing to play a part within the blended value context. However, the absence of a clear and straightforward cross-cutting regulation for blended value in the financial market generated fragmented approaches and intracategory variance among actors self-selecting in the blended value context, posing high risks of mistrustful and contradictory investment decisions. Thus, despite literature recently starting to investigate what distinguishes pure social- from pure economically oriented forms of investors from a strategic standpoint [11,12], we know relatively little about the heterogeneity of investors aiming at generating both social and economic value $[13,14]$, not only in terms of strategies but also in terms of investment decision. Current literature provided fragmented contributions: some scholars classified investors by exclusively referring to their declared aspirations to achieve social impact [6,14], while others focused exclusively on their investment portfolios [15]. In our work, we combine these two approaches to assess the alignment [16] between what investors declare to be and where they decide to invest. Accordingly, we analyze investors' objectives and their portfolio investment choices in terms of generation of social impact, proposing to address the following research questions: do investors operating in the context of blended value finance align their aspirations with their portfolio investment decisions? If yes, what influences this relationship?

To do this, we theorize around the blended value finance context. We introduce the concept of aspirations toward the creation of social impact as a specific baseline to distinguish investors in the blended value finance depending on the extent to which they are focused on generating social impact. As previously suggested, a peculiarity of our study is that aspirations toward social impact are assessed under two different perspectives: the investor and the investment portfolio. Indeed, investors operating in the blended value finance are, by definition, a specific type of hybrid organization [17] that seeks both social and economic value creation. At the same time, blended value actors invest in hybrid organizations that also need to perform socially and economically. Accordingly, we built on recent scholars' decisions to analyze organizations' mission statements for determining the degree of social aspirations in commercial business models [18]. We infer the aspirations toward social impact of investors by analyzing their mission statements at the investment firm level, as a proxy of the disclosed intentionality to achieve social impact [2,8]. Then, we assess the extent to which their pool of investees aspires to generate social impact. In doing so, we analyze for each investee its mission statements, to figure out the weight of socially oriented investments over the total number of investments in the portfolio.

Based on a sample of 75 investors active in the period 2010-2018 [19], we adopted a Fractional Logistic Regression model to test the alignment between investor aspirations and the overall aspirations of their respective investees (e.g., Impact Score). Our results show that the higher the investors' aspirations toward social impact, the higher the number of firms aspiring to pursue social return in their portfolios. Furthermore, our results suggest the existence of two boundary conditions for that relationship, operating at portfolio(i.e., GINI Index of the portfolio) and investor-level (i.e., Social Progress Index). They both positively influence the investor-portfolio alignment effect, so that: (i) investors tend to define a portfolio with more social businesses if investees are located in countries with higher levels of inequality (i.e., higher levels of GINI Index), and (ii) investors with stronger social aspirations located in countries with higher social and economic conditions (i.e., higher levels of Social Progress Index) are those who have more social businesses in their portfolio.

The paper is structured as follows. Firstly, the next section examines the framework of blended value and we introduce the concept of aspirations which is at the base of our strategy. Secondly, we formulate the hypotheses to be tested in the empirical part. 
Subsequently, the methodology is detailed, with focus on data, sample and econometric strategy. The results are, then, reported before being discussed in a final concluding section.

\section{Theoretical Background}

\subsection{The Framework of Blended Value Finance}

In the finance field, value is the outcome generated when investors provide support and the recipient organizations accomplish their missions [6]. In the mainstream finance, this value is translated as maximization of economic returns [20-22]. The concept of blended value redefines the understanding of value as an indivisible integration of three sources-economic, social and environmental—of returns from investments [4]. Blended value represents an expanding framework of investments in organizations with focus on the value that gets created not only in terms of economic returns, but also for the wellbeing of people, and the conservation of the planet [6]. Literature traditionally identifies impact investors as those actors more inclined to generate blended value, because they typically emphasize the condition of positive screens, that is, investors' search for organizations that pursue a positive social impact [23]. Impact investors provide financial support to organizations in order to pursue market-rate financial returns [24], but in addition to these financial objectives, impact investors seek for a positive social and/or environment impact of their investment $[25,26]$.

However, literature attempted to better explain blended value in terms of investments logics and investors' rationalities [27], involving a large spectrum of initiatives. Blended value is reflected in the capabilities to balance outcomes having conflicting economic and social logics, it and depends on the investors' sensemaking of means-end calculations, efficient mechanisms and measurable outcomes to maximize social and financial objectives. Accordingly, investment firms define their blended value proposition depending on how they shape the balance between social and economic logics, and internally organize processes, procedures, and actions to generate social impact and financial returns. Nevertheless, although blended value should represent a compass guiding investment strategies, the boundaries of what is and what is not blended value are hard to define. It is difficult to provide precise thresholds or rules for balancing social and economic objectives coherently with a straightforward definition of blended value finance.

For this reason, the finance industry lacks clear guidelines and regulations that help in distinguishing trustworthy socially oriented approaches while achieving financial returns [24]. Thus, the context of blended value presents loose boundaries, favoring the entry of heterogeneous actors free to declare the adoption of blended value approaches without reliable counterfactuals, making the context far from clear.

The result is that actors claiming such strategies are proliferating and are including also suspicious investment application. What is new in today's investment context is that, although investors tend to identify themselves according to a precise logic of value creation, there is not a clear distinction among investors in terms of which are the target recipients that reflect their aspirations of value, exposing them to the risk of mistrustful behavior.

Accordingly, we theorize on the fact that the rationality of means-end investors is a process of self-selection within the blended value framework that is currently given by the different aspirations of actors to generate social impact, but it requires to be completed with the understanding of the materialization of such aspirations [27]. As reported in Figure 1, the self-selection of investors in blended value contexts through their aspirations of social impact requires a deeper understanding of how blended value is materialized in the investment portfolios, to assess whether investment strategies are coherent with the investors' positioning. To help illustrate the concept, we provide some examples of investors combining different levels of blended value aspirations and with different levels of investments materialization. 


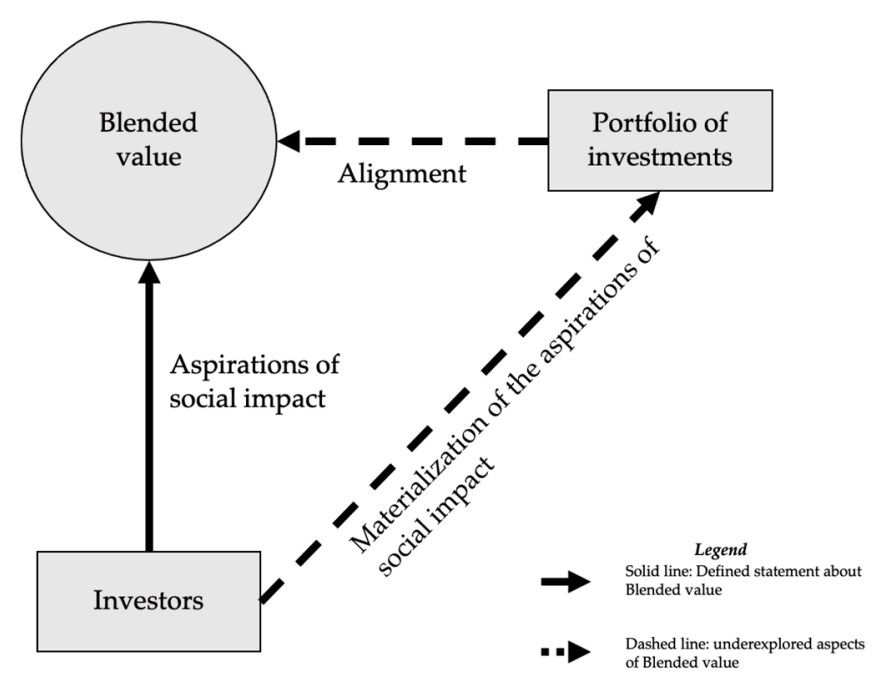

Figure 1. The framework of blended value finance. Source: production of authors.

An increasing number of investors from traditional mainstream finance-presenting low levels of social impact aspirations-are becoming attracted by investees generating social impact. To give an example, Allbirds is a company that is revolutionizing the shoe industry through eco-friendly recycled materials. Clearly, Allbirds uses the business to achieve social impact, being a secure target for impact investing strategies. Nevertheless, the interesting phenomenon is that Tiger Global Management, a traditional investor whose mission is the maximization of economic return, invested USD \$17.5 million in a Series B type equity to Allbirds in 2017. In support of this evidence, the famous statements of Larry Fink, the CEO of Black Rock—the largest asset management in the world—defined an important step for mainstream finance to increasingly adopt blended value approaches in their investment decisions. Nowadays, expecting investors that traditionally positioned themselves at a distance from blended value approaches to adopt impact investing strategies is no longer a heresy, requiring a better understanding of whether and how they are actually materializing social impact in their portfolio of investments.

It is also common to see investors adopting a moderated positioning with respect to aspirations to social impact. For example, some private equity and venture capital investors claim the introduction of Environmental, Social and Governance (ESG) principles in their investment practices as a way to include in the pipeline of investment opportunities only the investees that are aware of ESG issues [28]. This investment strategy is generally labelled as Socially Responsible Investments (SRI) [19], to distinguish it from strategies of impact investing; SRI strategies generally adopt a finance first approach to screen investment opportunities, requiring target investees to be compliant to ESG criteria. SRI tend to minimize the negative effects of business decisions having just "partial" aim to generate social impact.

On the other hand, investors presenting strong aspiration to generate social impact usually deliberate a precise and straightforward investment strategy that proposes to maximize the social impact of their investees [29]. More specifically, impact investors identify ex-ante impact criteria to drive the pipeline of investments, ensuring that each of them reflects the intentionality of social impact alongside their business models, the measurability of the outcomes generated, and the additionality for the context in which the social impact is enacted [2]. To do this, impact investors develop a theory of change across their investees, in which a logic model that starts from the activities of the investees should generate precise and measurable non-financial outputs with short- and long-term impacts for the society and the environment [1]. Conversely, investors adopting SRI strategies do not require investees to achieve specific social and environmental targets, but select them for their ESG compliance [28,30]. 
Interestingly, at the same time, those investors whose aspirations are fully oriented to generate social impact may end up allocating finance to investees whose aim is just to generate economic value. To make an example, BitGo is the world's largest processor of on-chain Bitcoin transactions, whose objective is to provide insurance and protection services to crypto-investors. In 2014, Capricorn Investment Group, an investor whose aim is to prove that "It is possible to invest profitably while driving sustainable positive change", invested USD \$12 million in a Series A type equity to BitGo in 2014. Alongside Capricorn, Goldman Sachs, an investment bank whose objectives are purely based on generating economic returns, invested in the company USD \$42 million in a Series B type equity (information extracted from www.crunchbase.com, accessed on 1 April 2021).

Accordingly, the result is a financial industry where different types of actors, guided by different investment objectives, simultaneously operate within the blended value context, bringing different perspectives and strategies in their investment decisions. These players position themselves in the blended value finance framework along a continuum where their mission differently balances social impact aspirations. At the one end, there are those actors with higher aspirations to social impact, with secondary consideration on economic return (e.g., socially oriented investors), while at the other end, there are those players presenting lower aspirations to social impact mainly moved by financial objectives (e.g., economically oriented investors) $[6,11,12]$. What is missing is connecting the dots between aspirations and actions. Investors state clearly their strategic self-selection positioning through their declared aspirations in their mission statements, but the materialization of coherent investment practices still has to be carefully disentangled.

\subsection{The Aspirations toward Social Impact}

As the framework of blended value finance raised the importance of a multiple set of sources of returns on the investments, practitioners and scholars struggled to find a way to measure the non-financial ones. Quantifying social impact is crucial but is often subjectively interpreted, a condition that prevents the agreement on methodologies to track, measure and report [31-35]. Because it cannot be measured through a uniform process, the framework of blended value is not characterized by a one-size-fits-all approach, and this downside enabled the proliferation of several interpretation and adoptions. Furthermore, as previously pointed out, within the blended value setting belong actors who deliberate strategies that differently generate social impact.

In order to shed a light on the blurred boundaries of blended value finance, we expand the concept of aspirations toward social impact. In the abstract formulation, we define aspirations as the extent to which an organization deliberates its overarching objectives of value creation. In particular, aspiration toward social impact refers to investors' willingness to create social impact through their activities, enacting the intentionality feature typical of impact investing strategies [2]. Literature in management often associated aspirations with the mission of organizations [36,37]: mission and vision statements are exceptionally helpful for organizing future goals and for defining aspirations of an organization. Aspirations are thus interpreted as the driving forces motivating a collective sense of action that reflects the purpose for which the organization has been established [37] and a means to help the sense-making generation within the organization [38]. In line with this approach, investors' mission statements represent the means for organizations to set the aspirational directions through which their future actions are guided [39]. Yet, in the context of finance, where investors' actions correspond to investment decisions, the aspirations toward social impact can (and have to) be assessed not only from the investors' side, but also from the perspective of the investees included in their portfolios. In other words, the blended value finance framework presented in Section 2.1 considers aspirations from both the supply and the demand side of the financing process. The supply side captures the extent to which economically oriented investors aspire to generate social impact, as identified in their mission statements. The demand side reflects the aspirations towards social impact of the investees' mission statements (which identify investment portfolio choices). The missing 
link is understanding to what extent supply and demand side are aligned, which is the objective of this work.

\section{Hypothesis}

\subsection{The Alignment of Aspirations toward Social Impact between Investor and Investees}

To gain a more nuanced understanding of how investors generate blended value, it is critical to investigate the variety of strategic actions that investors may adopt in response to certain levels of aspiration toward social impact. If an investor's aspiration is the natural engine of investment choices, then investors should combine a portfolio of investees in which their aspiration towards social impact is aligned with their deliberated strategies.

The concept of alignment is strongly relevant within the context of blended value finance. First, as previously pointed out, aspirations towards social impact can be assessed at the level of the investor and at the level of portfolio investees. Even though both types of aspiration fall within the same overall organizational practice (i.e., engagement in social value creation), investors could put more emphasis on one type than the other, creating a misalignment between them. Second, actors within the blended value setting are characterized by declared strategies which emphasize different levels of social impact generation and which may imply different levels of alignment with the overall portfolio aspirations. As far as the investors' side, some missions explicitly state strong aspirations of generating social impact, combined with the achievement of economic sustainability, such as in the case of impact investors. Other investors, however, propose to target companies that primarily answer market needs through commercial activities by either excluding harmful practices or engaging in responsible practices at project level. Under a portfolio perspective, a similar heterogeneity in terms of aspirational level toward social impact can be identified.

Investors could finance hybrid organizations, that is, commercial entities whose mission is characterized by a social objective [40-44], for which social impact is achieved through a profitable business model [45]. Profitable investments could also be found in firms that have a precise commercial objective but engage in project-level socially responsible practices, such as corporate philanthropy and volunteering. Differently from hybrid organizations, these entities do not integrate the aspirations to social impact in their mission statements, but adopt what literature refers as Corporate Social Responsibility (CSR) as an alternative business strategy that often generates financial benefits [46-50]; in this case, the aspiration of generating social impact is not as strong and central as in the case of hybrid organizations. Finally, other firms show a clear and straightforward commercial identity as a way to generate superior economic returns. These entities have no social aspirations, regardless of either integrating social impact in the commercial objectives or using CSR strategies. High-tech start-ups are a typical example of firms aspiring for superior economic returns in this way [51,52].

The distinction between these two levels of analysis allows for a plurality of combinations and may generate different levels of alignment. However, extant literature suggests the importance of searching for a strong alignment of activities, like in the case of internal and external corporate socially responsible actions [16]. Alignment creates credibility and builds legitimacy [53] because it allows an easier recognition of value generated from actions. Alignment has often been investigated in the literature of organizational categories [54]. The membership to an organizational category - a socially accepted system of norms and values - provides rewards to organizations as long as their identity coherently aligns with such norms and values [55,56]. A recent study by Hawn and Ioannou [16] also suggests that greater alignment of activities allows organizations to achieve greater market value. In accordance with these results, we expect that investors whose missions present higher social-impact aspirations adopt impact investing strategies, targeting hybrid organizations, due to a strong similarity and congruence of aspirations toward social impact. As impact investing strategies aspire to generate social impact through profitable entrepreneurial ventures, hybrid investees aspire to achieve social impact through busi- 
ness. Thus, the portfolio composition in favor of investees having higher aspirations to social impact should be greater for investors with higher aspirations to social impact than for investors with lower aspirations to social impact. For the same reasons, players pursuing more financially oriented objectives should target companies with a clear and straightforward commercial identity. Accordingly, we formulate the following hypothesis.

Hypothesis 1. The higher the investors' aspirations toward social impact, the greater the number of firms pursuing social impact in the investor's portfolios.

\subsection{The Boundary Conditions: Context Characteristics at the Portfolio and Investor Levels}

Literature treating traditional finance and the venture capital industry recognized the context as an important driver to better understand investment decisions. Traditional financial investors are strongly interconnected with the context in which they are located and in which they are investing $[57,58]$. The context is considered a variable of uncertainty for financial operations [59] because investments in entrepreneurial ventures typically target risky industries. Accordingly, investors mitigate uncertainty of the investment risks by carefully deciding where to direct financial flows to investees and where to establish their main offices [60-62].

Considering the setting of blended value finance, investors should mitigate the uncertainty of the investment risk by considering contexts yielding high social returns from their investees [63], a perspective that within the mainstream finance setting is not considered. As several researchers indicated, the contexts in which high-tech and entrepreneurial activities are well-developed are those in which there is potential for maximizing economic returns [51], but the preferred contexts for maximizing social returns still have to be disentangled.

Investors more oriented to the financial returns mitigate the risk of investing in highly evolving and uncertain industries by adopting proximity strategies [62], targeting a context in which they have higher control, reduce information asymmetry and benefit from entrepreneurial advancements [64]. On the other hand, investors with higher aspirations to social impact should find strong opportunities to generate social impact by investing in countries where there are higher levels of social inequalities, so that the increased investment risk of operating in troubled countries is mitigated by possibility to generate higher marginal social impact. The additionality feature of impact investing suggest that the more financial actors are impact investors, the more their investees should generate social value added in the context in which they operate. Literature refers that social impact aspirations mostly fit where the investments would have been avoided by any other investor and thus not executed [65]. Moreover, impact investors tend to operate in contexts where the public sector is inefficient and fail to grant minimum rights and services to the population [65]. Accordingly, we assert that different levels of social inequality in the country in which investees are located influence the deliberated strategies of investments and investment decisions.

Hypothesis 2. The alignment between mission and investments is influenced by the levels of social inequalities of the investees in the investment portfolio, such that the higher the investors' aspirations toward social impact, the more investments are located in countries with high levels of social inequalities.

An additional element generally taken into consideration by the extant literature on entrepreneurial finance is the context in which the investor is localized, in particular for what concerns the effects of legal regulation [66], financial vibrance [67] and the entrepreneurial texture [20]. As a matter of fact, scholars identified that the most relevant levers through which a national context affects investors' activities are the degree of law enforcements for investors' protection and the country's ease of entrepreneurial inception [21], leaving mainly unexplained potential effects of social conditions on the country of the investors [66]. 
Few studies attempted to deepen on the social characteristics of the investors' context to better understand the investment decisions. In their study, [68] show that VC industry bears the imprinting of both at macro (cultural, and social progresses) and micro (people, markets, capital and support organizations) level factors, suggesting to further advance research on the macro side. Nye and Wasserman [69] show that levels of cultural progresses and basic infrastructures in India and Israel determined the presence of investors characterized by approaches and outcomes that coherently reflected public development strategies. These studies suggest that the directions of development achieved by countries over the years coherently conditioned the investment strategies and decisions of investors. We assert that, in our context of investigation, the degree of social and environmental development in the country in which the investor operates influence the deliberated strategies of investments and investment decisions. More precisely, we hypothesize that:

Hypothesis 3. The alignment between mission and investments is influenced by the social and environmental development of the investor's countries, such that the higher the investors' aspirations toward social impact, the more they are located in countries with high levels of social progresses.

\section{Data and Method}

\subsection{Sample Identification}

For this study, we build our sample exploiting a list of investors observed by the Global Impact Investing Network (GIIN). The GIIN is an entity collecting aggregate financial flows for societal impact and perfectly fits with the purpose of our work: that is, capturing the mission-investment alignment within the common setting of blended value finance. Up to 2018, the GIIN tracked 226 investors that self-selected as investors pursuing blended value [70]. For each of them, we checked on CrunchBase all the available financing rounds completed. Crunchbase is a leading platform for extracting information on public and private companies, mostly related to the activities of venture capital and private equity spheres.

In order to have a homogeneous context, not influenced by external conditions, we consider deals completed from 2010 to 2018, to neutralize potential effects of the financial crisis of the years 2008-2009 on investment decisions. We collected information on 1342 deals involving 1114 target ventures financed by 75 investors for a total of USD \$86.3 billion. Because of our portfolio approach, we include investors from the list of the GIIN that registered financing rounds in at least one ventures. The sample of investors is characterized by 37 investors located in the US, and 38 investors located in the rest of the world (see Table 1).

Table 1. Country of origin of investors of our sample.

\begin{tabular}{cccc}
\hline Country of Origin & Frequency & Percent & Cum \\
\hline Australia & 3 & 4.00 & 4.00 \\
\hline Belgium & 1 & 1.33 & 5.33 \\
\hline Canada & 2 & 2.67 & 8.00 \\
\hline Finland & 1 & 1.33 & 9.33 \\
\hline France & 3 & 4.00 & 13.33 \\
\hline India & 6 & 8.00 & 21.33 \\
\hline Liechtenstein & 1 & 1.33 & 22.67 \\
\hline Luxembourg & 1 & 1.33 & 24.00 \\
\hline Netherlands & 5 & 6.67 & 30.67 \\
\hline
\end{tabular}


Table 1. Cont.

\begin{tabular}{cccc}
\hline Country of Origin & Frequency & Percent & Cum \\
\hline Singapore & 1 & 1.33 & 32.00 \\
\hline South Africa & 1 & 1.33 & 33.33 \\
\hline Spain & 2 & 2.67 & 36.00 \\
\hline Switzerland & 5 & 6.67 & 42.67 \\
\hline United Kingdom & 6 & 8.00 & 50.67 \\
\hline United States & 37 & 49.33 & 100 \\
\hline Total & 75 & 100.00 &
\end{tabular}

\subsection{Variables}

\subsubsection{Dependent Variable}

Our dependent variable is a measure of social impact at the portfolio level (Impact_Score), which identifies the extent to which investment portfolios are specialized (or not) towards investees that aspire towards creating social (and/or environmental) impact. In order to develop our Impact Score measure, we analyzed the mission statements, the value proposition and the business operation of each investee in the portfolio. We took inspiration from a recent paper from Gamble, Parker and Moroz [18], in which the authors explored the mission statements of organizations to figure out the extent to which social impact is respectively integrated, partially integrated and not integrated in the business model. Accordingly, we adopted a content analysis approach for the evaluation of the mission statements of the investees by checking both Crunchbase- and website-level information: the aim of the content analysis was to disentangle the extent to which investees consider the aspirations to generate social impact in their business models. Thus, we categorized mission statements into three categories: full aspirations to social impact, partial aspirations to social impact and no aspirations to social impact.

First, social ventures with aspirations to social impact are those entities whose business model is exploiting a business activity to achieve a societal objective integrating social aims in their commercial operations [71], such as B Corps or Social Enterprises. They are recognized as hybrid organizations by management literature [40] as they represent entities that combine conflicting multiple identities (i.e., social and for profit). Within our reasoning, hybrid ventures portray for-profit investees that aspire towards generating social impact.

Second, ventures which engage in Corporate Social Responsibility (CSR) initiativessuch as corporate philanthropy, corporate volunteering or social marketing campaigns-are entities with pure commercial objective that adopt responsible practices. For our reasoning, these ventures do not integrate social objectives in their business activities but engage in socially responsible practices that may support commercially driven objectives, with partial aspiration towards generating social impact. Within the measurement of the Impact Score, the ventures with full aspiration towards generating social impact are weighted more (1 point) than ventures with partial aspiration towards generating social impact ( 0.5 points).

Finally, investors may decide to allocate resources to ventures that do not aspire towards generating social impact. These ventures have a straightforward commercial objective regardless of engaging with responsible practices. Within the reasoning of the Impact Score, these ventures are weighted zero in terms of social impact. From a portfolio perspective, the more an investor allocates resources to an increased number of ventures that aspire to generate social impact [72,73], the closer the Impact Score will be to one. Conversely, the more an investor allocates resources to an increased number of ventures 
generating no impact, the more the Impact Score will be close to zero. Summarizing, the impact score is assessed as:

$$
\begin{aligned}
& \text { Impact Score }_{\mathrm{t}}=\frac{\mathrm{n} \text { of investments with full aspiration to social } \text { impact }_{\mathrm{t}}}{\mathrm{n} \text { of investments in portfolio }} \mathrm{t} \times 1 \\
& +\frac{\mathrm{n} \text { of investments with partial aspiration to social } \text { impact }_{t}}{\mathrm{n} \text { of investments in portfolio }} \times 0.5 \\
& +\frac{\mathrm{n} \text { of investments with no social impact }}{\mathrm{n} \text { of investments in portfolio }} \times 0
\end{aligned}
$$

The construction of the variable followed a two-step codification for the assessment of 1114 ventures in the portfolio of investors: in the first step, one of the authors and one independent researcher expert in the field of social impact simultaneously skimmed through investees' webpage and Crunchbase's page, coding them according to the level of aspiration towards social impact disclosed. Then, following Bolzani et al. [74], in the second step, the full team of authors addressed disagreements by revising on a common code first-step preliminary codings.

\subsubsection{Independent Variable}

Our independent variable defines a scale determining the extent to which each investor presents aspirations towards social impact in their mission statements (impact_investor_scale). When available, we also checked the vision and value proposition statements. The scale ranges from 0 to 10 . The value of 0 defines investors purely oriented towards economic returns (score of 0 ), thus having no aspirations to social impact. The value of 10 refers to investors purely oriented towards generating social impact, thus having strong aspirations to social objectives. In agreement with Bugg-levine and Emerson [6], investors with aspirations to social objectives tend to be those closer to the definition of impact investors, whose mission statements explicitly refer to the achievement of social impact. For a more robust approach, we cross-checked investors' mission statements on their websites and controlled for possible mission drifts along their lifetime.

"We invest in ambitious founders using technology to tackle big social and environmental problems that aim to radically improve millions of lives."-Bethnal Green Ventures their mission statement in 2019.

We identify investors having no aspirations to social impact as those whose mission is to maximize economic returns by strategically investing in specific industries and/or geographical locations regardless of the generation of social impact [70].

"Fledge Capital provides capital solutions to companies with robust business models, exceptional management teams, potential for growth and which are profitable (with profits exceeding R20-million)"-Fledge Capital mission statement in 2019.

The more the score increases, the more investors are inclined to achieve social objectives through their investment actions. The coding approached followed the two-step procedure as for the dependent variable (see Section 4.2.1).

\subsubsection{Moderators}

The variables representing our boundary conditions are the standardized measure of the average GINI index (Countres' GINI index was extracted for one year (2010) from the World Bank website.) of the portfolio of investees (GINI_portfolio) and the SPI (Social Progress Index) level (SPI_investor) of the investors' countries (Countries' SPI was extracted from socialprogress.org, accessed on 1 April 2021).

The GINI index tracks the level of social inequalities in a country, using a score measuring the distribution of richness within countries. It is a measure that makes welfare comparisons through the evaluation of income distributions, evidencing the general conditions of the opportunities that could arise in a specific country.

The social progress of countries is tracked by the Social Progress Index (SPI), which measures the extent to which countries provide for the social needs of their citizens. It is 
based on three dimensions: basic human needs, foundations of wellbeing and opportunity. These dimensions incorporate information on 52 indicators. The index is published by the non-profit Social Progress Imperative, and is based on the studies of Amartya Sen, Douglass North and Joseph Stiglitz. Other studies have exploited the SPI Social Progress Index to best differentiate countries' social performances [75].

\subsubsection{Control Variables}

We include a variety of control variables to minimize the effect of omitted variable bias and improve the specification of our model. For our approach, control variables are meant to deepen the understanding of the mission-portfolio alignment. First, we include the technological intensity of the investees in the portfolio (technology_intensity) obtained from the industrial categorization provided by Crunchbase. The variable ranges from 0 to 1 and indicates the weight of high-tech investees on the total number of investees in the portfolio. Traditionally, investment firms are attracted by the economic returns achievable by investing in ventures with high technological potential (Hall and Lerner 2010).

We also include a set of control variables from the investor side: the geographical location (US_investor), the size (portfolio_size) and the number of positive exits (exits) IPOs, M\&As, buy-outs—obtained from investments made in the time span of 2010-2018.

\subsubsection{Econometric Specifications}

As the Impact Score is a continuous variable ranging from 0 to 1 , we adopt a Fractional Logistic Regression model. For variables bounded between 0 and 1, literature suggests a regression model that avoids misspecification and dubious statistical validity other than capturing particular nonlinear relationships typical of outcome variables ranging between 0 and 1. Papke and Wooldridge [76] synthetize the econometric methodologies on the generalized linear models (GLM) and on the quasi-likelihood literature in order to develop more robust estimations in case of fractional response outcomes. Simple linear methodologies such as Ordinary Least Squared (OLS) regressions are not flexible enough to guarantee that predicted variables lie in the unit interval.

Impact_Score $=\alpha+\beta_{1}$ impact_investor_scale $+\beta_{2}$ GINI_portfolio $+\beta_{3}$ SPI_investor $+\beta_{4}$ exits $+\beta_{5}$ portfolio_size $+\beta_{6}$ technology_intensity $+\beta_{7}$ us_investor $+\varepsilon$

\section{Analyses}

\subsection{Descriptive Statistics}

As reported in Table 2, the distribution of the Impact Score of our sample has a median of 0.6 and a mean of 0.59 . Out of the investment portfolios, $61 \%$ are in the range between 0.5 and 1 regarding their Impact Score. Interestingly, investors whose portfolio is completely specialized towards investees that aspire towards generating social impact (Impact Score $=1$ ) are only 3, while those completely specialized towards no impact (Impact Score $=0$ ) are only 4 . These data evidence that around $90 \%$ of all the investors in the sample include, in some way, social impact in their portfolios. The average value of GINI Index within our sample is 38.8. Low levels of GINI index (20/30) indicate countries with low levels of social inequality, while high levels of GINI index (50/60) indicate countries with high levels of social inequality. The average SPI index is 83.2, a value higher than the population score of SPI (63.4) (Data extracted from the official website of the SPI (socialprogress.org), accessed on 1 April 2021).

Interestingly, the mean for technology_intensity (0.36) and its standard deviation (0.25) indicate that portfolios are structured with generally low levels of technological intensity somehow contrasting the common wisdom of venture capital and private equity targets. The average portfolio size is 15 companies. 
Table 2. Descriptive statistics.

\begin{tabular}{cccccc}
\hline Variable & Obs & Mean & Std. Dev. & Min & Max \\
\hline Impact_Score & 75 & 0.59 & 0.25 & 0 & 1 \\
\hline Impact_Investor_scale & 75 & 5.96 & 2.88 & 0 & 10 \\
\hline Gini_portfolio & 75 & $\cong 0$ & $\cong 1$ & -2.98 & 4.51 \\
\hline Spi_investor & 75 & 83.15 & 8.41 & 56.57 & 89.08 \\
\hline Exits & 75 & 3.38 & 6.37 & 0 & 33 \\
\hline Portfolio_size & 75 & 14.84 & 19.46 & 1 & 130 \\
\hline Technology_intensity & 75 & 0.36 & 0.25 & 0 & 1 \\
\hline US_investor & 75 & 0.49 & 0.50 & 0 & 1 \\
\hline
\end{tabular}

Table 3 shows the matrix of correlations. Notably, our measure of impact score is positively correlated with the variable impact investor scale (0.3760), and US investors tend to have a larger portfolio size (0.2743). All remaining correlations were generally acceptable. The levels of correlation of the variables are generally lower than the critical threshold of 0.7 [77], which signals potential collinearity issues. We conducted additional checks for multicollinearity through the Variance Influence Factor (VIF). Since VIF values are smaller than 0.5 , our variables do not evidence concerns [78], thus we can consider the model not biased by collinearity issues (see Table 4).

Table 3. Matrix of correlations.

\begin{tabular}{|c|c|c|c|c|c|c|c|c|}
\hline & Impact_Investor_Scale & Gini_Portfolio & SPI_Investor & Exits & Portfolio_Size & Technology_Intensity & US_Investor & Impact_Score \\
\hline $\begin{array}{c}\text { Impact } \\
\text { investor_scale }\end{array}$ & 1.00 & & & & & & & \\
\hline Gini_portfolio & -0.0732 & 1.00 & & & & & & \\
\hline SPI_investor & -0.0870 & 0.1815 & 1.00 & & & & & \\
\hline Exits & $-0.3921 *$ & 0.0263 & 0.0620 & 1.00 & & & & \\
\hline Portfolio_size & -0.0985 & -0.0044 & 0.0412 & $0.6422 *$ & 1.00 & & & \\
\hline Technology_intensity & -0.0287 & 0.0066 & 0.2021 & 0.1689 & 0.1015 & 1.00 & & \\
\hline US_investor & -0.0919 & 0.2263 & 0.1157 & $0.2588 *$ & $0.2743 *$ & 0.0586 & 1.00 & \\
\hline Impact_score & $0.3760 *$ & -0.1273 & 0.1276 & -0.1166 & 0.0944 & -0.2323 & 0.3364 & 1.00 \\
\hline
\end{tabular}

* Correlations are significant at 0.01 .

Table 4. Multicollinearity test.

\begin{tabular}{ccc}
\hline & VIF & Tolerance \\
\hline Exits & 2.09 & 0.4774 \\
Portfolio_size & 1.73 & 0.5797 \\
Impact_investor_scale & 1.26 & 0.7918 \\
Us_investor & 1.26 & 0.7954 \\
Technology_inensity & 1.13 & 0.8831 \\
GINI_portfolio & 1.18 & 0.8498 \\
Spi_investor & 1.08 & 0.9247 \\
\hline Mean VIF & 1.39 & \\
\hline
\end{tabular}

\subsection{Regression Results}

Table 5 shows the results of our regression analyses conducted with STATA. Model 1 examines the main effect of the aspiration towards social impact of the investors' deliberated strategies on the Impact Score of their investment portfolios. The coefficient of the main effect is positive and statistically significant $(p<0.001)$ : the level of Impact Score is higher for investors whose missions have higher aspirations towards social impact. These 
results demonstrate that the investors whose mission is social-impact-oriented tend to invest in ventures that aspire to social impact. Thus, we find support for our Hypothesis 1. This first result highlights a general alignment between the mission and the investment strategy of investors.

Table 5. Models of regressions.

\begin{tabular}{|c|c|c|c|c|}
\hline Impact_Score & Model 1 & Model 2 & Model 3 & Model 4 \\
\hline \multicolumn{5}{|l|}{ Main independent variables } \\
\hline Impact_investor_scale & $\begin{array}{c}0.0745^{* * *} \\
(0.0268)\end{array}$ & $\begin{array}{l}0.0737^{* * *} \\
(0.0272)\end{array}$ & $\begin{array}{l}-0.320^{*} \\
(0.164)\end{array}$ & $\begin{array}{l}-0.289 \\
(0.188)\end{array}$ \\
\hline Gini_portfolio & $\begin{array}{l}-0.123 \\
(0.0953)\end{array}$ & $\begin{array}{l}-0.318^{* *} \\
(0.158)\end{array}$ & $\begin{array}{l}-0.120 \\
(0.0934)\end{array}$ & $\begin{array}{l}-0.310 * \\
(0.159)\end{array}$ \\
\hline SPI_investor & $\begin{array}{c}0.00102 \\
(0.00640)\end{array}$ & $\begin{array}{l}0.000208 \\
(0.00595)\end{array}$ & $\begin{array}{l}-0.0295^{* *} \\
(0.0148)\end{array}$ & $\begin{array}{l}-0.0279 \text { * } \\
(0.0164)\end{array}$ \\
\hline Exits & $\begin{array}{c}-0.0245^{*} \\
(0.0149)\end{array}$ & $\begin{array}{l}-0.0238 * \\
(0.0138)\end{array}$ & $\begin{array}{l}-0.0224 \\
(0.0152)\end{array}$ & $\begin{array}{l}-0.0219 \\
(0.0142)\end{array}$ \\
\hline Portfolio_size & $\begin{array}{c}0.00610 \\
(0.00393)\end{array}$ & $\begin{array}{l}0.00638 * \\
(0.00375)\end{array}$ & $\begin{array}{c}0.00534 \\
(0.00389)\end{array}$ & $\begin{array}{c}0.00567 \\
(0.00373)\end{array}$ \\
\hline Technology_intensity & $\begin{array}{l}-0.353 \\
(0.295)\end{array}$ & $\begin{array}{l}-0.399 \\
(0.291)\end{array}$ & $\begin{array}{l}-0.375 \\
(0.296)\end{array}$ & $\begin{array}{l}-0.417 \\
(0.290)\end{array}$ \\
\hline US_investor & $\begin{array}{l}0.688^{* * *} \\
(0.153)\end{array}$ & $\begin{array}{l}0.616^{* * *} \\
(0.153)\end{array}$ & $\begin{array}{l}0.678^{* * *} \\
(0.151)\end{array}$ & $\begin{array}{l}0.611^{* * *} \\
(0.152)\end{array}$ \\
\hline $\begin{array}{c}\text { Impact_investor_scale } \times \\
\text { Gini_portfolio }\end{array}$ & & $\begin{array}{l}0.0452 * \\
(0.0260)\end{array}$ & & $\begin{array}{l}0.0437 * \\
(0.0263)\end{array}$ \\
\hline $\begin{array}{c}\text { Impact_investor_scale } \times \\
\text { SPI_investor }\end{array}$ & & & $\begin{array}{l}0.00467^{* *} \\
(0.00215)\end{array}$ & $\begin{array}{l}0.00430 * \\
(0.00240)\end{array}$ \\
\hline Constant & $\begin{array}{l}-0.481 \\
(0.485)\end{array}$ & $\begin{array}{l}-0.357 \\
(0.450)\end{array}$ & $\begin{array}{l}2.115^{*} \\
(1.130)\end{array}$ & $\begin{array}{c}2.030 \\
(1.277)\end{array}$ \\
\hline \multicolumn{5}{|l|}{ Model diagnostics } \\
\hline Loglikelihood & -46.77 & -46.51 & -46.65 & -46.41 \\
\hline Chi-squared & 0.00 & 0.00 & 0.00 & 0.00 \\
\hline Pseudo R2 & 0.0741 & 0.0794 & 0.0766 & 0.0815 \\
\hline Number of observations & 75 & 75 & 75 & 75 \\
\hline
\end{tabular}

As per the control variables, we also find significant relationships between the exit strategies of firms and the Impact_Score $(p<0.1)$, but in a negative direction, suggesting that portfolios with a strong aspiration towards social impact register fewer possibilities to obtain a positive exit. This is an interesting result, confirming the fact that impact investors tend to operate with more patient capital (Miller and Wesley 2010). Furthermore, a strong positive statistically significant relationship is evidenced between the US location of investors and the Impact Score $(p<0.001)$, suggesting that investors more inclined to invest in social businesses are located in the US, where the VC market is more developed.

In Models 2 and 3, we investigate the effect of the interactions between the characteristics of the portfolio (GINI index of the investees) and the context of the investor (SPI) with mission-investment alignments. The interaction between investors' aspirations toward social impact and the GINI index of the investees is positive and statistically significant $(p<0.1)$ : this result confirms that an investment portfolio whose investees are located in countries with high levels of social inequalities influences the mission-investment alignment. Thus, we find support for our Hypothesis 2. More specifically, for investors with higher aspirations towards social impact, investees tend to be located in countries with 
higher levels of inequalities. As for our control variables, in Model 2 we also find statistically significant relationship between the size of the investment portfolio and the impact score $(p<0.1)$, meaning that investors with a larger portfolio of investments tend to be those that invest the most in ventures with higher aspirations towards social impact.

The interaction between investors' aspirations toward social impact and the SPI of the country in which the investor is located is shown in Model 3. Its effect is positive and statistically significant $(p<0.05)$ : this result confirms that investors with higher aspirations towards social impact located in socially and environmentally developed countries tend to invest more in ventures with social objectives. More specifically, the mission-investments alignment depends on the social progress of the country in which the investor is located. Thus, we find support for our Hypothesis 3.

In order to better interpret these results, we plot the predicted value of the Impact Score across the whole range of the aspirations towards social impact for high and low levels of the GINI and SPI indexes (one standard deviation above and below their means). Figures 2 and 3 exhibits the two plots.

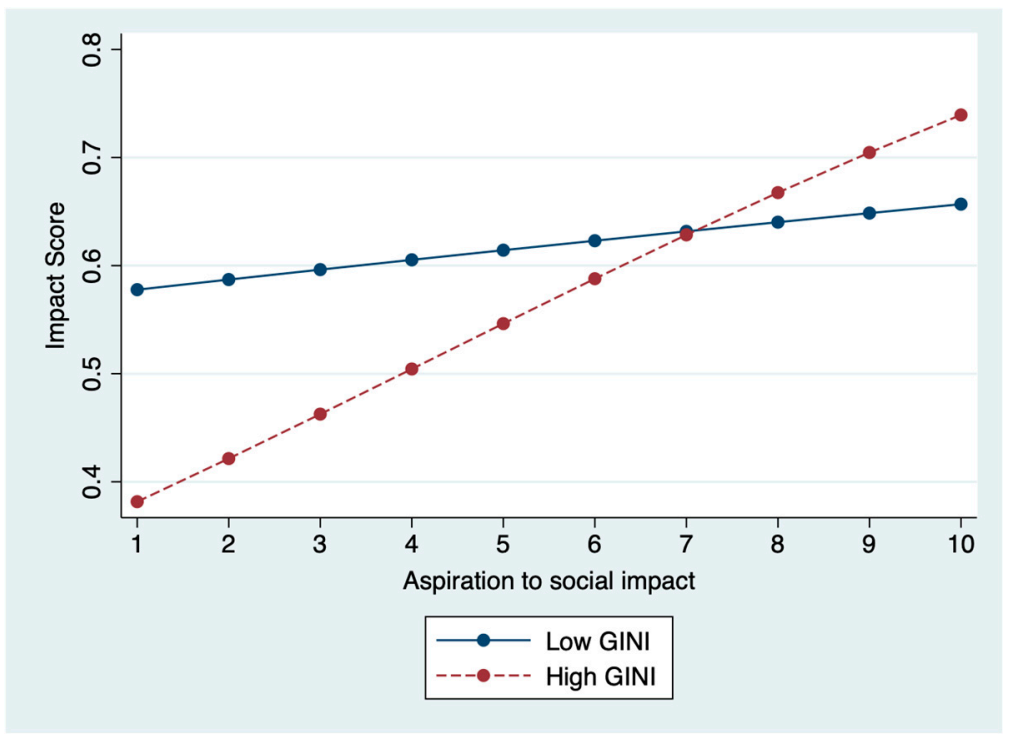

Figure 2. Plots of the predicted value from Model 2. Source: STATA.

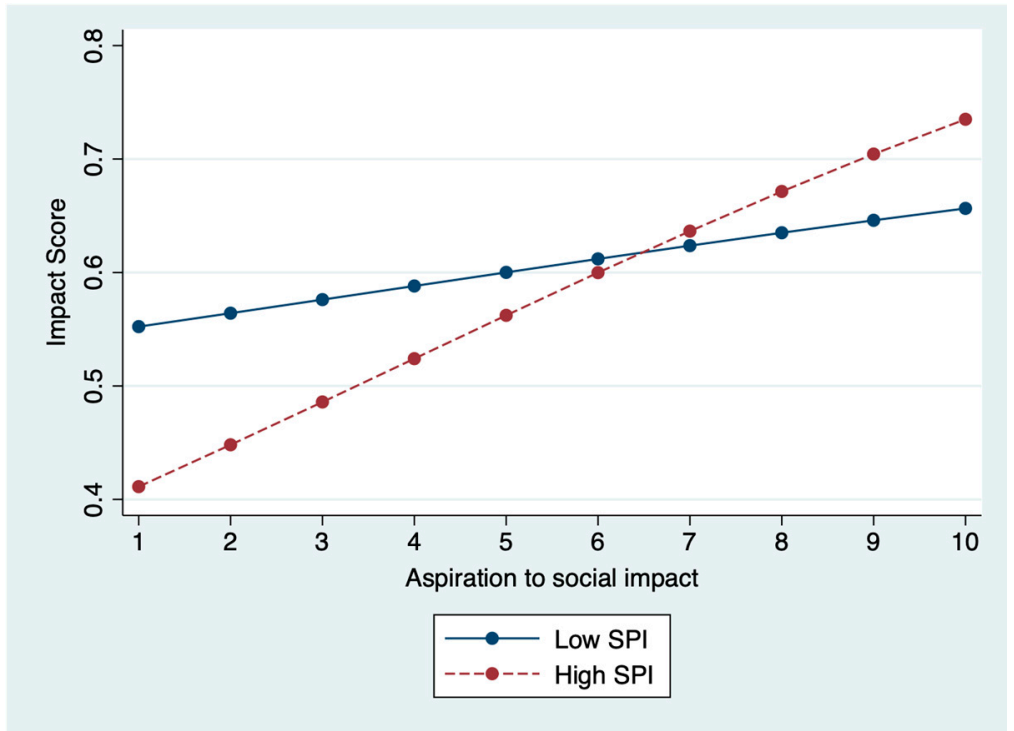

Figure 3. Plots of the predicted value from Model 3. Source: STATA. 
In Figure 2 we report the predicted value of the aspirations towards social impact for a range of levels of the standardized GINI index of the portfolio of investees (between one standard deviation above and below the mean). We assessed the marginal effect of the aspirations towards social impact at the investor level on the aspirations towards social impact the portfolio level as positive and statistically significant for levels of the GINI index greater than -0.2 (the variable ranges from -2.9 to 4.5 ) and increasing as the levels of GINI of the portfolio increases. This means that for very low levels of the GINI of the investees, the social aspiration towards social impact of the investor is not aligned with the social aspiration of the portfolio.

In Figure 3 we report the predicted value of the aspirations towards social impact for a range of levels of the SPI of the investor's country (between one standard deviation above and below the mean). We assessed that the marginal effect of the aspirations towards social impact at the investor level on the aspirations towards social impact on the portfolio level was positive and statistically significant for level of the SPI higher than 77 (the variable ranges from 56 to 89). This means that for very low levels of the SPI of the investor's country, the social aspiration towards social impact of the investor is not aligned with the social aspiration of the portfolio.

\section{Robustness Check}

We conducted additional analyses to improve the robustness of our econometric model.

First, considering the relevant portion of US-based investors-the distribution of the variable US_investors evidence that $49 \%$ of the observations concern investors localized in the US - we tested our hypothesis on a sample considering only non-US-based investors (39 observations). In Table 6, we report the regression analysis, showing that the main effect and our boundary conditions are statistically significant, confirming our structure of hypothesis also in the restricted sample of non-US-based investors.

Table 6. Models of regressions for the non-US-based investors.

\begin{tabular}{|c|c|c|c|c|}
\hline Impact Score & Model 1 & Model 2 & Model 3 & Model 4 \\
\hline \multicolumn{5}{|l|}{ Main independent variables } \\
\hline Impact_investor_scale & $\begin{array}{l}0.135^{* * *} \\
(0.0497)\end{array}$ & $\begin{array}{c}0.156^{* * * *} \\
(0.0464)\end{array}$ & $\begin{array}{c}-0.335 * * \\
(0.137)\end{array}$ & $\begin{array}{l}-0.205 \\
(0.165)\end{array}$ \\
\hline Gini_portfolio & $\begin{array}{c}-0.0269 \\
(0.104)\end{array}$ & $\begin{array}{c}-0.377^{* *} \\
(0.177)\end{array}$ & $\begin{array}{c}-0.0218 \\
(0.101)\end{array}$ & $\begin{array}{c}-0.356^{*} \\
(0.182)\end{array}$ \\
\hline SPI_investor & $\begin{array}{l}-0.00407 \\
(0.00678)\end{array}$ & $\begin{array}{l}-0.00410 \\
(0.00616)\end{array}$ & $\begin{array}{c}-0.0409 * * * \\
(0.0144)\end{array}$ & $\begin{array}{c}-0.0322 \text { ** } \\
(0.0154)\end{array}$ \\
\hline Exits & $\begin{array}{c}0.0436 \\
(0.0492)\end{array}$ & $\begin{array}{c}0.0268 \\
(0.0446)\end{array}$ & $\begin{array}{c}0.0537 \\
(0.0513)\end{array}$ & $\begin{array}{c}0.0355 \\
(0.0471)\end{array}$ \\
\hline Portfolio_size & $\begin{array}{c}0.00741 \\
(0.00699)\end{array}$ & $\begin{array}{l}0.00930 * \\
(0.00547)\end{array}$ & $\begin{array}{c}0.00544 \\
(0.00654)\end{array}$ & $\begin{array}{c}0.00770 \\
(0.00560)\end{array}$ \\
\hline Technology_intensity & $\begin{array}{c}-0.0379 \\
(0.320)\end{array}$ & $\begin{array}{l}-0.203 \\
(0.335)\end{array}$ & $\begin{array}{c}-0.0585 \\
(0.324)\end{array}$ & $\begin{array}{l}-0.211 \\
(0.332)\end{array}$ \\
\hline Impact_investor_scale x Gini_portfolio & & $\begin{array}{c}0.0838^{* *} \\
(0.0365)\end{array}$ & & $\begin{array}{c}0.0790 * * \\
(0.0374)\end{array}$ \\
\hline Impact_investor_scale x SPI_investor & & & $\begin{array}{c}0.00559 * * * \\
(0.00215)\end{array}$ & $\begin{array}{l}0.00428 * \\
(0.00233)\end{array}$ \\
\hline Constant & $\begin{array}{l}-0.662 \\
(0.592)\end{array}$ & $\begin{array}{l}-0.642 \\
(0.513)\end{array}$ & $\begin{array}{c}2.453 * * * \\
(0.893)\end{array}$ & $\begin{array}{l}1.737 * \\
(1.007)\end{array}$ \\
\hline \multicolumn{5}{|l|}{ Model diagnostics } \\
\hline Loglikelihood & 10.23 & 19.37 & 20.84 & 24.33 \\
\hline Chi-squared & 0.1154 & 0.0222 & 0.0134 & 0.0184 \\
\hline Pseudo R2 & 0.0514 & 0.0718 & 0.0579 & 0.0755 \\
\hline Number of observations & 38 & 38 & 38 & 38 \\
\hline
\end{tabular}


To give further evidence for the reliability of the sample, we conducted the MannWhitney test to assess whether US-based and non-US-based investors are two significantly different groups. The results presented in Table 7 show that we cannot reject the null hypothesis that the groups are equal, confirming that our main sample of observation does not suffer from US-based biases.

Table 7. Mann-Whitney test.

\begin{tabular}{cccc}
\hline US_Investor & Observations & Rank Sum & Expected \\
\hline 0 & 38 & 1525.5 & 1501.5 \\
1 & 37 & 1400.5 & 1424.5 \\
Combined & 75 & 2926 & 2926 \\
\hline
\end{tabular}

Ho: Impact_investor_scale Us_investor $=0=$ Impact_investor_scale Us_investor $=1$. Prob $>|z|=0.7992$.

\section{Discussion}

In this paper, we refer to the concept of aspiration toward social impact generation to investigate, through a portfolio perspective, whether the deliberated strategies of investors operating in the setting of blended value align with their investment decisions. We evidenced that investors declaring higher aspirations towards social impact are those whose portfolio of investees present higher aspirations towards social impact, confirming positive and significant mission-portfolio alignment. Moreover, this effect is positively influenced by the context at the portfolio and at the investor level, so that investment portfolios whose investees are located in countries with high levels of social inequalities influence the mission-investment alignment, and investors with higher aspirations towards social impact located in socially and environmentally developed countries tend to invest more in ventures with social objectives.

The paper shed a light on the setting of blended value through the development of the measure of Impact Score. We built on extant literature attempts to identify comprehensive measures to determine social impact integration in finance-oriented firms [18]. Our measure, looking at investment portfolio composition, helped us in clarifying the approach of actors operating in blended value finance, demonstrating that investors' objectives are aligned with investments they make. As a matter of fact, the proliferation of actors purely economically oriented are still far from actually characterizing their portfolio of investments in social businesses, even though the resonance of sporadic investments in social impact may have biased public opinion on a possible revolution of the finance industry. In addition to the development of a comprehensive measure that help assessing blended value strategies, the conceptual mechanisms that consider the alignment between aspirations of social impact and their materialization within the investment portfolio contribute to better define the boundaries of impact investing. The issue of alignment (or misalignment) is particularly salient in blended value finance given that an increasing number of actors are worldwide making ex-ante prosocial claims without properly accounting for their ex-post investment decisions [19]. In their review of impact investing literature, Höchstädter and Scheck [14] stressed future researchers to increasingly include the role and characteristics of investees to better understand the impact investing industry. In our work, we adopted the concept of aspirations, and we defined the various organizational requirements of impact investees to measure the alignment between the overall impact of investees and investors.

We contributed to the literature that treats the alignment between intentions and actions, highlighting that the context in which the investor and the investees are located have effects on such an alignment. These results contribute to the literature in impact investing by addressing current gaps related to the effects of the context for explaining the financial flows for social impact: current research on impact investing generally focused on explaining the progresses of the global impact investment community, analyzing specific sectors, such as agriculture, but not considering context-specific features of the geographical localization of financial flows [73,74]. Accordingly, the paper offers indications of the additionality of impact investing strategies: as additionality suggests that 
impact creation should be localized in contexts where impact investors can make the difference [2], our results confirm that investors with higher social aspirations tend to localize their interventions in countries with higher social inequalities. Interestingly, investors with higher social aspirations tend to look for additionality regardless of their proximity with the investees: from our results, the same investors tend to be located in countries that are mostly developed, signaling a coherent additionality approach for their investment strategies. To the best of our knowledge, this is the first attempt to make a quantitative investigation with respect to the additionality objectives for impact investing.

Moreover, this paper offers a contribution to the conceptual schema of social investment provided by Nicholls [27]. Our findings help to shed a light on the dynamics for which certain means-end rational approaches reflect an alignment between aspirations and investment decisions, making a step ahead for a better understanding of where impact investors operate and where they tend to be localized.

This work is not without limitations. We acknowledge that the sampling technique generated observation losses that pose doubts on the generalization of results. Future research attempts may be willing to adopt alternative data sources for the replication of the analysis in a different sample of blended value investors. We are aware of potential endogeneity inquiries for our econometric model. Currently, our interest in investigating the relationship between the dependent variable-Impact Score, measuring the level of social aspirations of the portfolio-and the main independent variable-Impact Investor Scale, as a proxy of social impact aspirations for investors' missions-is motivated by the phenomenon-driven proliferation of investors claiming blended value strategies, for which the field lacks relevant knowledge. Additional tests for endogeneity such as the introduction of instrumental variables or the Heckman procedures may be further developed.

\section{Conclusions}

This paper opens up future research opportunities to explore further determinants for mission-portfolio alignment, such as the performance of the investors and investees, the reputation, the expertise of the investors, and syndications. Researchers may exploit the concept of alignment under a different level of analysis, investigating how the structure of the governance, or the set of inter-organizational alliances are respectively aligned with the deliberated strategies. Then, the paper leaves open questions for further exploitation, such as: what are the payoffs of having high aspirations towards social impact? What are the antecedents of having higher aspirations towards social impact? Why do investors differently aspire to social impact?

Finally, the paper offers insights for policy makers and practitioners. The blended value finance framework can support policy makers to identify an overarching mechanism for assessing the reliability of investors' positioning with respect to blended value. Even though investors in Europe will benefit from the Sustainable Finance Disclosure Regulation (SFDR) 2019/2088, the rush for joining the sustainability bandwagon will involve an increasingly greater number of factors, raising the risks of greenwashing. In addition, the financial industry is globalized and lacks a top-down mechanism for setting straightforward, cross-cutting boundaries for blended value finance. Our framework of blended value finance builds on the aspirations of both the supply and demand sides for assessing the coherence between investors' decisions and their investment portfolios, providing a solution for raising the barriers of entry.

Our arguments offer a better understanding of the extent to which investors operate ethically: as a matter of fact, assessing the alignment of objectives and actions in terms of social aspirations contributes to revealing the professional honesty of financial actors, a necessary condition in an era in which the concept of social impact is spreading across the whole financial industry.

Author Contributions: Conceptualization, L.B. and L.T.; methodology, L.B. and R.F.; software L.B. and R.F.; validation, L.T., R.F. and L.B.; formal analysis, L.B.; investigation, L.B.; data curation, L.B.; 
writing—original draft preparation, L.B., L.T. and R.F.; writing—review and editing, L.B., L.T. and R.F.; visualization, L.B.; supervision, L.T. and R.F. All authors have read and agreed to the published version of the manuscript.

Funding: This research received no external funding.

Institutional Review Board Statement: Not applicable.

Informed Consent Statement: Informed consent was obtained from all subjects involved in the study.

Data Availability Statement: The data presented in this study are available on request from the corresponding author. The data are not publicly available due to privacy restrictions.

Conflicts of Interest: The authors declare no conflict of interest.

\section{References}

1. Ebrahim, A.; Rangan, V.K. What Impact? A Framework for Measuring the Scale and Scope of Social Performance. Calif. Manag. Rev. 2014, 56, 118-141. [CrossRef]

2. Calderini, M.; Chiodo, V.; Michelucci, F.V. The Social Impact Investment Race: Toward an Interpretative Framework. Eur. Bus. Rev. 2018, 30, 66-81. [CrossRef]

3. Arena, M.; Azzone, G.; Bengo, I. Performance Measurement for Social Enterprises. Voluntas 2015, 26, 649-672. [CrossRef]

4. Emerson, J. The Blended Value Proposition: Integrating Social and Financial Returns. Calif. Manag. Rev. 2003. [CrossRef]

5. Phillips, S.D.; Johnson, B. Inching to Impact: The Demand Side of Social Impact Investing. J. Bus. Ethics 2019, 1-15. [CrossRef]

6. Bugg-levine, A.; Emerson, J. Transforming How We Make Money. Innov. Technol. Gov. Glob. 2011, 6, 9-18. [CrossRef]

7. Agrawal, A.; Hockerts, K. Impact investing strategy: Managing conflicts between impact investor and investee social enterprise. Sustainability 2019, 11, 4117. [CrossRef]

8. Bengo, I.; Borrello, A.; Chiodo, V. Preserving the Integrity of Social Impact Investing: Towards a Distinctive Implementation Strategy. Sustainability 2021, 13, 2852. [CrossRef]

9. Bonini, S.; Emerson, J. Maximizing Blended Value-Building beyond the Blended Value Map to Sustainable Investing, Philanthropy and Organizations. 2005. Available online: http:/ / community-wealth.org (accessed on 1 April 2021).

10. Moore, M.L.; Frances, R.W.; Nicholls, A. The Social Finance and Social Innovation Nexus. J. Soc. Entrep. 2012, 3, 115-132. [CrossRef]

11. Dees, G.J.; Anderson, B.B. Strategies for Spreading Social Innovations. Stanf. Soc. Innov. Rev. 2004, 1, 24-32. [CrossRef]

12. Schaltegger, S.; Beckmann, M.; Hockerts, K. Sustainable entrepreneurship: Creating environmental solutions in light of planetary boundaries. Int. J. Entrep. Ventur. 2018, 10, 131-152. [CrossRef]

13. Scarlata, M.; Walske, J.; Zacharakis, A. Ingredients Matter: How the Human Capital of Philanthropic and Traditional Venture Capital Differs. J. Bus. Ethics 2017, 145, 623-635. [CrossRef]

14. Höchstädter, A.K.; Scheck, B. What's in a name: An analysis of impact investing understandings by academics and practitioners. J. Bus. Ethics 2015, 132, 449-475. [CrossRef]

15. Brandstetter, L.; Lehner, O.M. Opening the market for impact investments: The need for adapted portfolio tools. Entrep. Res. J. 2015, 5, 87-107. [CrossRef]

16. Hawn, O.; Ioannou, I. Mind the gap: The interplay between external and internal actions in the case of corporate social responsibility. Strateg. Manag. J. 2016, 37, 2569-2588. [CrossRef]

17. Battilana, J.; Lee, M. Advancing Research on Hybrid Organizing. Acad. Manag. Ann. 2014, 37-41. [CrossRef]

18. Gamble, E.N.; Parker, S.C.; Moroz, P.W. Measuring the integration of social and environmental missions in hybrid organizations. J. Bus. Ethics 2019, 1-14. [CrossRef]

19. EUROSIF. European SRI Study. 2018, pp. 1-68. Available online: https://www.eurosif.org/wp-content/uploads/2018/11/ European-SRI-2018-Study.pdf (accessed on 1 April 2020).

20. Baygan, G.; Freudenberg, M. The Internationalization of Venture Capital Activity in OECD Countries: Implications for Measurement and Policy; STI Working Papers 2000/7; OECD: Paris, France, 2000.

21. Dimov, D.; Gordon, M. Literature Survey of Venture Capital Support Schemes in Europe. 2001. Available online: https:// www.researchgate.net/profile/Gordon-Murray-2/publication/267399816_Literature_Survey_of_Venture_Capital_Support_ Schemes_in_Europe/links/54c20ebb0cf2d03405c5f31f/Literature-Survey-of-Venture-Capital-Support-Schemes-in-Europe.pdf (accessed on 1 April 2020).

22. Mike, W.; Pruthi, S.; Lockett, A. International Venture Capital Research: From Cross-Country Comparisons to Crossing Borders. Int. J. Manag. Rev. 2005, 7, 135-165. [CrossRef]

23. Cooper, L.; Evnine, J.; Finkelman, J.; Huntington, K.; Lynch, D. Social finance and the postmodern portfolio: Theory and practice. J. Wealth Manag. 2016, 18, 9-21. [CrossRef]

24. Block, J.H.; Hirschmann, M.; Fisch, C. Which criteria matter when impact investors screen social enterprises? J. Corp. Financ. 2021, 66, 101813. [CrossRef]

25. Brest, P.; Born, K. When can impact investing create real impact. Stanf. Soc. Innov. Rev. 2013, 11, $22-31$. 
26. Harji, K.; Jackson, E.T. Accelerating Impact: Achievements, Challenges and What's Next in Building the Impact Investing Industry; The Rockefeller Foundation: New York, NY, USA, 2012.

27. Nicholls, A. The institutionalization of social investment: The interplay of investment logics and investor rationalities. J. Soc. Entrep. 2010, 1, 70-100. [CrossRef]

28. Eccles, R.G.; Lee, L.E.; Stroehle, J.C. The social origins of ESG: An analysis of Innovest and KLD. Organ. Environ. 2020, 33, 575-596. [CrossRef]

29. O'Donohoe, N.; Leijonhufvud, C.; Saltuk, Y.; Bugg-Levine, A.; Brandenburg, M. Impact Investments: An Emerging Asset Class; JP Morgan: New York, NY, USA, 2010; p. 6.

30. Cort, T.; Esty, D. ESG Standards: Looming Challenges and Pathways Forward. Organ. Environ. 2020, 33, 491-510. [CrossRef]

31. Maas, K. Corporate Social Performance: From Output Meaasurement to Impact Measurement. Bus. Soc. 2009, 46. [CrossRef]

32. Maas, K.; Kellie, L. Social Impact Measurement: Classification and Methods. In Environmental Management Accounting and Supply Chain Management; Springer: Berlin, Germany, 2011.

33. Hinkin, T.R.; Bruce, T.J.; Enz, C.A. Scale Construction: Developing Reliable and Valid Measurement Instruments. J. Hosp. Tour. Res. 1997, 21, 100-120. [CrossRef]

34. Costa, E.; Caterina, P. Social Impact Measurement: Why Do Stakeholders Matter? Sustain. Account. Manag. Policy J. 2016, 7, 99-124. [CrossRef]

35. Mura, M.; Mariolina, L.; Pietro, M.; Daniela, B. The Evolution of Sustainability Measurement Research. IJMR 2018, 20, 661-695. [CrossRef]

36. Bart, C.K.; Maureen, H. Mission Statements in Canadian Hospitals. J. Health Organ. Manag. 2004, 18, 92-110. [CrossRef]

37. Bowen, S.A. Mission and vision. In The International Encyclopedia of Strategic Communication; Wiley Online Library: Hoboken, NJ, USA, 2018; pp. 1-9.

38. Gergen, K.J.; Whitney, D. Technologies of representation in the global corporation: Power and polyphony. In Postmodern Management and Organization Theory; Boje, D.M., Gephart, R.P., Thatchenkery, T.J., Eds.; Sage: Thousand Oaks, CA, USA, 1996; pp. 331-357.

39. Ireland, R.; Duane, M.; Hitt, A. Mission Statements: Importance, Challenge, and Recommendations for Development. Bus. Horiz. 1992, 35, 34-42. [CrossRef]

40. Battilana, J.; Silvia, D. Building Sustainable Hybrid Organizations: The Case of Commercial Microfinance Organizations. Acad. Manag. J. 2010, 53, 1419-1440. [CrossRef]

41. Pache, A.C.; Filipe, S. Inside the Hybrid Organzation: Selective Coupling as a Repsonse to Competing Institutional Logics. Acad. Manag. J. 2013, 56, 972-1001. [CrossRef]

42. Haigh, N.; Andrew, J.H. The New Heretics: Hybrid Organizations and the Challenges They Present to Corporate Sustainability. Organ. Environ. 2014, 27, 223-241. [CrossRef]

43. Lee, M. The Viability of Hybrid Social Ventures. Acad. Manag. Proc. 2014, 2014, 13958. [CrossRef]

44. Battilana, J.; Metin, S.; Anne, C.P.; Jacob, M. Harnessing Productive Tensions in Hybrid Organizations: The Case of Working Integration Social Enterprises. Acad. Manag. J. 2015, 58, 1658-1685. [CrossRef]

45. Haffar, M.; Cory, S. How Organizational Logics Shape Trade-off Decision-Making in Sustainability. Long Range Plan. 2019, 52, 101912. [CrossRef]

46. Godfrey, P.C. The Relationship between Corporate Philanthropy and Shareholder Wealth: A Risk Management Perspective. Acad. Manag. Rev. 2005, 30, 777-798. [CrossRef]

47. Godfrey, P.C.; Craig, M.B.; Jared, M.H. The Relationship between Corporate Social Responsibility and Shareholder Value: An Empirical Test of the Risk Management Hypothesis. Strateg. Manag. J. 2009, 30, 425-445. [CrossRef]

48. Flammer, C. Corporate Social Responsibility and Shareholder Reaction: The Environmental Awareness of Investors. Acad. Manag. J. 2013, 56, 758-781. [CrossRef]

49. Cheng, B.; Ioannis, I.; George, S. Corporate Social Responsibility And Access To Finance. Strateg. Manag. J. 2014, 35, 1-23. [CrossRef]

50. Eccles, R.G.; Ioannou, I.; Serafeim, G. The impact of corporate sustainability on organizational processes and performance. Manag. Sci. 2014, 60, 2835-2857. [CrossRef]

51. Hall, B.H.; Josh, L. The Financing of RED and Innovation; NBER Working Paper Series; NBER: Cambridge, MA, USA, 2010.

52. Gompers, P.A. Optimal Investment, Monitoring, and the Staging of Venture Capital. J. Financ. 1995, 50, 1461-1498. [CrossRef]

53. Berrone, P.; Gelabert, L.; Fosfuri, A. The Impact of Symbolic and Substantive Actions on Environmental Legitimacy; Working Paper WP-778; IESE Business School: Barcelona, Spain, 2009.

54. Durand, R.; Paolella, L. Category stretching: Reorienting research on categories in strategy, entrepreneurship, and organization theory. J. Manag. Stud. 2013, 50, 1100-1123. [CrossRef]

55. Zuckerman, E.W. The categorical imperative: Securities analysts and the illegitimacy discount. Am. J. Sociol. 1999, 104, 1398-1438. [CrossRef]

56. Zuckerman, E.W. On networks and markets by Rauch and Casella, eds. J. Econ. Lit. 2003, 41, 545-565. [CrossRef]

57. Gupta, A.K.; Sapienza, H.J. Determinants of venture capital firms' preferences regarding the industry diversity and geographic scope of their investments. J. Bus. Ventur. 1992, 7, 347-362. [CrossRef] 
58. Norton, E.; Tenenbaum, B.H. Specialization versus diversification as a venture capital investment strategy. J. Bus. Ventur. 1993, 8 , 431-442. [CrossRef]

59. Matusik, S.F.; Fitza, M.A. Diversification in the venture capital industry: Leveraging knowledge under uncertainty. Strateg. Manag. J. 2012, 33, 407-426. [CrossRef]

60. Bresnahan, T.; Gambardella, A.; Saxenian, A. ‘Old economy'inputs for 'new economy'outcomes: Cluster formation in the new Silicon Valleys. Ind. Corp. Chang. 2001, 10, 835-860. [CrossRef]

61. Fosfuri, A.; Rønde, T. High-tech clusters, technology spillovers, and trade secret laws. Int. J. Ind. Organ. 2004, 22, 45-65. [CrossRef]

62. Lerner, J. Venture capitalists and the oversight of private firms. J. Financ. 1995, 50, 301-318. [CrossRef]

63. Miller, T.L.; Curtis, L.W. Assessing Mission and Resources for Social Change: An Organizational Identity Perspective on Social Venture Capitalists' Decision Criteria. Entrep. Theory Pract. 2010, 34, 705-733. [CrossRef]

64. Chen, H.; Gompers, P.; Kovner, A.; Lerner, J. Buy local? The geography of venture capital. J. Urban Econ. 2010, 67, 90-102. [CrossRef]

65. So, I.; Staskevicius, A. Measuring the "Impact" in Impact Investing 2015. Retrieved from Harvard Business School. Available online: http:/ / www.hbs.edu/socialenterprise/Documents/MeasuringImpact.pdf (accessed on 15 December 2020).

66. Wright, M.; Sapienza, H.; Busenitz, L. Introduction. Venture Capital; Edward Elgar: Cheltenham, UK, 2003; Volume I.

67. Bruton, G.D.; Ahlstrom, D.; Wan, J.C.C. Turnaround in Southeast Asian firms: Evidence from ethnic Chinese communities. Strateg. Manag. J. 2003, 24, 519-540. [CrossRef]

68. Bygrave, W.D.; Timmons, J. Venture Capital at the Crossroads. In University of Illinois at Urbana-Champaign's Academy for Entrepreneurial Leadership Historical Research Reference in Entrepreneurship; The Academy of Entrepreneurial Leadership: Champaign, IL, USA, 1992.

69. Nye, D.; Wasserman, N. Patterns of VC evolution: Comparing the Israeli and Indian venture capital industries. J. Priv. Equity 1999, 3, 26-48.

70. Global Impact Investing Network. Annual Impact Investor Survey. 2018. Available online: https://thegiin.org/research/ publication/annualsurvey2018 (accessed on 15 December 2020).

71. Spieth, P.; Sabrina, S.; Thomas, C.; Daniel, E. Value Drivers of Social Businesses: A Business Model Perspective. Long Range Plan. 2019, 52, 427-444. [CrossRef]

72. Kish, Z.; Fairbairn, M. Investing for profit, investing for impact: Moral performances in agricultural investment projects. Environ. Plan. A Econ. Space 2018, 50, 569-588. [CrossRef]

73. Watts, N.A. Investing for Impact: Finance and Farming in the Southern Highlands of Tanzania. Ph.D. Thesis, University of Cambridge, Cambridge, UK, 2018.

74. Bolzani, D.; Fini, R.; Napolitano, S.; Toschi, L. Entrepreneurial teams: An input-process-outcome framework. Found. Trends Entrep. 2019, 15, 56-258. [CrossRef]

75. Alonso-Martínez, D. Social progress and international patent collaboration. Technol. Forecast. Soc. Chang. 2018, 134, 169-177. [CrossRef]

76. Papke, L.E.; Wooldridge, J.M. Econometric methods for fractional response variables with an application to 401 (k) plan participation rates. J. Appl. Econom. 1996, 11, 619-632. [CrossRef]

77. Dormann, C.F.; Elith, J.; Bacher, S.; Buchmann, C.; Carl, G.; Carré, G.; Lautenbach, S. Collinearity: A review of methods to deal with it and a simulation study evaluating their performance. Ecography 2013, 36, 27-46. [CrossRef]

78. O'brien, R.M. A caution regarding rules of thumb for variance inflation factors. Qual. Quant. 2007, 41, 673-690. [CrossRef] 